\title{
Development of Semicontinuous Measurement System of Ionic Species in $\mathbf{P M}_{2.5}$
}

\author{
Sang-Bum Hong, ${ }^{+,-a}$ Wonil Chang, ${ }^{\ddagger}, \mathrm{b}$ Chang-Hee Kang, ${ }^{\ddagger}$ and Jai H. Lee ${ }^{\dagger}$ \\ †Adranced Emironmental Monitoring Research Center (ADERC). Department of Enwironmental Science and Engineering. \\ Gu'angit Institute of Science and Techologv (GIST), Gwangit 500-701, Korea. E-mail: hong909:akopri.re.kr \\ -Department of Chemistry and Research Institute for Basic Sciences. Cheju National Chiversity, Jeju 690-756, Korea \\ Recerved December 2. 2008, Accepted Mav 12, 2009
}

\begin{abstract}
A new method to semicontinuously determine $\mathrm{PM}_{2 \leq s}$ ionic species with a short time resolution is described in detail. In this sy'stem, a particle collection section (nixing part, particle collection chamber, and air/liquid separator) was developed. A Y-type connector was used to mix steam and an air sample. The particle collection chamber was constructed in the fonm of a helix coil and was cooled by a water circulation system. Particle size growth occurred due to the high relative humidity and water absorbed particles were efficiently collected in it. Liquid samples were drained out with a short residence time $(0.08-0.1 \mathrm{~s})$. The air/liquid separator was also newly designed to operate efficiently when the flow rate of the air sample was $16.7 \mathrm{~L} \mathrm{~min}{ }^{-1}$. For better performance, the system was optimized for particle collection efficiency with various types of test aerosols such as $\left(\mathrm{NH}_{4}\right)_{2} \mathrm{SO}_{4}, \mathrm{NaCl}, \mathrm{NH}_{\downarrow} \mathrm{HSO}_{4}$, and $\mathrm{NH}_{\downarrow} \mathrm{NO}_{3}$. The particle collection efficiencies were almost $100 \%$ at different concentration levels in the range over $500 \mathrm{~nm}$ in diameter but $50-90 \%$ in the range of $50-500 \mathrm{~nm}$ under the following experimental conditions: 15 coil turns, a water flow rate for steam generation of $0.65 \mathrm{~mL} \mathrm{~min}^{-1}$, and an air sample flow rate of $16.7 \mathrm{~L} \mathrm{~min}^{-1}$. Finally, for atmospheric applications, chenical compositions of $\mathrm{PM}_{2}$ s were deternined with a time resolution of 20 min on January $11-24,2006$ in Seoul, Korea, and the chemical characteristics of $\mathrm{PM}_{2.5}$ ions were investigated.
\end{abstract}

Key Words: $\mathrm{PM}_{2}$. Particle collection section. Semicontinuous measurement ș'stem

\section{Introduction}

Particles less than $2.5 \mu \mathrm{m}$ in diameter $\left(\mathrm{PM}_{z .5}\right)$ in the atmosphere can play important roles in radiative forcing. ${ }^{1}$ visibility degradation. ${ }^{-}$heterogeneous atmospheric chemistry, ${ }^{3}$ and human health. ${ }^{-}$Indirectly they act as cooling agents by increasing albedo and the lifetime of shallow marine clouds. ${ }^{5}$ They also contribute to acidification and entrophication of land and water resources via wet and dry deposition. ${ }^{6}$

As a result. much research has been conducted to examine these issues. In order to investigate the chemical characteristics of these particles, a reasonably short time resolution is essential since the particles changes their properties over a short time in the atmosphere. ${ }^{1.8}$ However. the widely used filter methods cannot capture the rapid changes in the chemical compositions of particles owing to their relatively long sampling frequencies. In addition. these methods was reported to suffer from sampling artifacts such as reactions on filter media and loss of semi-rolatile species during and after collection. ${ }^{9}$ Recently. to overcome the drawbacks of the filter methods. a variety of semicontinuous measurement methods have been developed over the last decade ${ }^{1(1-16}$

$\mathrm{PM}_{z \leq 5}$ in the atmospheric environment typically includes most of the total number of particles. surface area, and a large fraction of the mass. However. collection of particles in the range of $0.1-1.0 \mu \mathrm{m}$ is not simple because particle removal mechanisms. such as diffusion and impaction are least efficient in this regime. ${ }^{1:-18}$ Thus. an appropriate device needs to

\footnotetext{
apresent address : Korea Polar Research Institute, KORDI, Incheon 406-840. Korea. "present address: Department of Earth and Environmental Sciences, Korea University, Seoul 136-701, Korea
}

be developed to allow effective collection by utilizing a semicontinuous measurement system. Previous studies have suggested that such fine particles could be collected efficiently via impaction after increasing their size by water vapor saturation. Aerosol particles can take up water vapor and then grow to a certain equilibrium size as the relative humidity $(\mathrm{RH})$ reaches the deliquescence point. Hot steam has typically been injected to increase the $\mathrm{RH}$ in a system with small particles.

Simon and Dasgupta (1995) used a mixing chamber in the form of a circular tube connected with a short segment of gently curved PTFE tubing, where superheated steam $\left(\sim 300^{\circ} \mathrm{C}\right)$ was introduced along with an aerosol saniple at $10 \mathrm{~L} \mathrm{~min}^{-1}$. The particles were further grown in a cooled stainless steel maze and then collected in a gas/liquid separator. The steam jet aerosol collector (SJAC) gathered the grown droplets in a cyclone at a sample flow rate of $20-60 \mathrm{~L} \mathrm{~min}^{-1}$ after mixing steam and an aerosol sample. ${ }^{\text {"l }}$ Concentration colunns have typically been installed in ion chromatography systems due to their sensitivities. A prototype particle-into-liquid sampler (PILS), operating at a flow rate of $5 \mathrm{~L} \mathrm{~min} \mathrm{~min}^{-1}$. has been developed to mpidly speciate and quantify small liquid samples, without using a concentrator. Furthermore. an improved analyzer. operating at a flow rate of $16.7 \mathrm{~L} \mathrm{~min}^{-1}$. was developed and used successfully in an airplane measurement campaign. 1920

In this study. a semicontinuous system to measure $\mathrm{PM}_{25}$ ionic species was developed. In principle. our system is identical to the well established particle collection system described in previous reports. ${ }^{11-12.14}$ However. the particle collection section (mixing part. particle collection chamber. and air/liquid separator) was specifically built and tested. In particular, a particle collection chamber was developed to not only induce 
the size growth of small particles. but also to efficiently collect water-absorbed samples. This is an advantage of our system over that of previous ones. As a performance test. collection efficiencies using test aerosols. such as $\left(\mathrm{NH}_{4}\right)_{2} \mathrm{SO}_{4}$. $\mathrm{NaCl} . \mathrm{NH}_{4} \mathrm{HSO}_{4}$. and $\mathrm{NH}_{4} \mathrm{NO}_{3}$, were conducted. Finally. field monitoring results for ionic species in $\mathrm{PM}_{25}$ were also presented.

\section{Experimental Section}

Aemsol sampling and interference gas removal. In order to collect $\mathrm{PM}_{z .5}$ and to remove acidic and basic gases in ambient air, were used a PM: $:$ cyclone (URG-2000-30 EH) with a 2.5 $\mu \mathrm{m}$ cutoff at a sample flow rate of $16.7 \mathrm{~L} \mathrm{~min}^{.1}$ and a denuder systems (URG-2000-30 $\times 2+2-3 C S S$ ) with a collection efficiency of $99 \%$ at a sample flow rate of $16.7 \mathrm{~L} \mathrm{~min}^{-1}$. The denuders used in this sy stem can effectively retain gaseous species. such as $\mathrm{HNO}_{3} . \mathrm{HNO}_{2}, \mathrm{SO}_{2}$. and $\mathrm{NH}_{3}$. Because the diffusion coefficients of gas molecules are typically four orders of magnitude larger than the smallest atmospheric particle, quantitative removal of gas molecules by diffusion is possible. Under laminar flow conditions and with a vertical deployment of the denuder tube. gravitational settling of aerosol particles can be avoided and the aerosol can be transmitted efficiently. The coating solution was prepared according to the use and maintenance manual for URG antular denuders. ${ }^{\text {?].2. }}$

Particle collection section. Figure 1 shows a schematic diagram of the measurement sy stem and Figure 2 displays important components of the particle collection section (mixing part. particle collection chamber, and air/liquid separator) made of Pyrex glass. The aerosol samples passing through the gas removal denuder tubes were introduced to a $\mathrm{Y}$-connector mixing area. and then were mixed initially with hot water vapor (Fig. 2a). The flow direction of aerosol samples at a higher flow rate $\left(16.7 \mathrm{~L} \mathrm{~min}^{-1}\right)$ than that of the water vapor $\left(\sim 0.75 \mathrm{~L} \mathrm{~min}^{-1}\right)$ was forced to change abniptly. to induce a turbulent flow of the air stream. This can enhance the rapid and efficient mixing of the steam and the aerosol. before water vapors condense on the wall surface of the mixing area. Water vapors cannot condense on an aerosol surface and thus cannot contribute to size growth once they are liquidized on another surface. The steam generator was specifically designed to produce homogeneous water vapor. Steam was produced in a stainless steel (SS) tube (ID 1/8". $12 \mathrm{~cm}$ ) connected with a coil of SS tubing. through which distilled water was pumped: its temperature was controlled at $\sim 110^{\circ} \mathrm{C}$

The most prominent feature of our system was a particle collection chamber designed in a helix coil form. as shown in Figure $2 \mathrm{~b}$. Except for an $8 \mathrm{~cm}$ length at each end, the rest of the tube (Pyrex glass. $3 \mathrm{~mm}$ i.d.) was turned. Generally a helixtype coil sampler is used to continuously collect soluble gaseous species with high Henry's law constants in online measurement sy stems. ${ }^{-3}$ but it was utilized to verify' a particle collector in our system. This was surrounded by a jacket through which cooling water was introduced and a temperature close to $20^{\circ} \mathrm{C}$ was maintained to increase the $\mathrm{RH}$ in it. After air samples were initially mixed with hot steam in the mixing area. they began to absorb water vapor while they passed

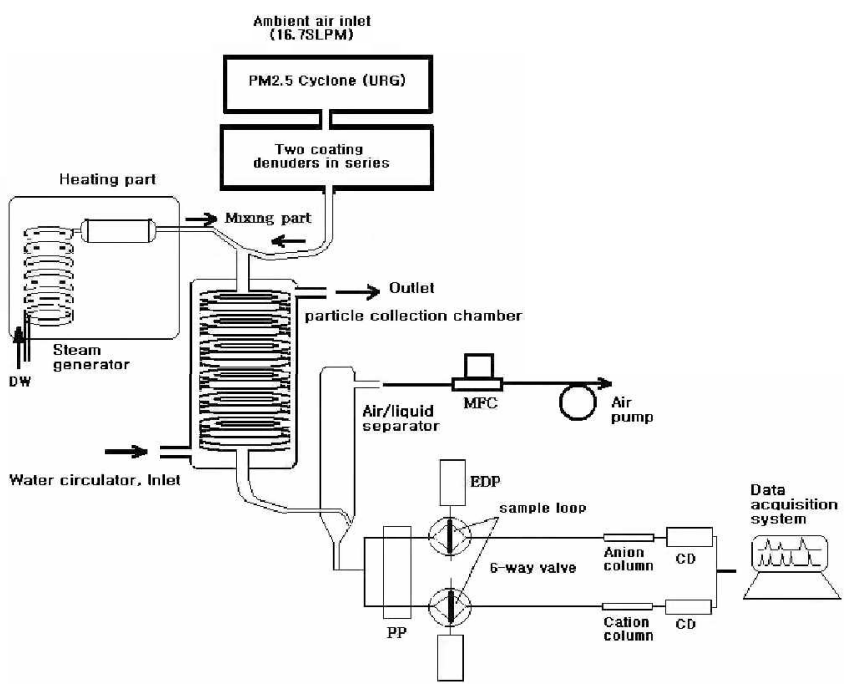

Figure 1. Schematic diagram of semi-continuous measurement system, consisting of denuders, a steam generator, á particle collection section (mixing part, particle collection chamber, and air/liquid separator), and IC system ( $\mathrm{DW}$; distilled water, MF C; mass flow controller, EDP; eluent delivery pump, PP, peristaltic pump, $C D$; conductivity detector)

through the particle collection chamber with a high $\mathrm{RH}$. The sizes of particles increase due to the spontaneous absorption of water at RHs higher than the deliquescence relative humidity $(\mathrm{DRH})$ and the nasses of water-absorbed samples also increase significantly: ${ }^{18.24-2 ?}$ The $\mathrm{RH}$ in the chamber was $\sim 300 \%$ under the following experimental conditions: an air sample flow rate of $16.7 \mathrm{~L} \mathrm{~min}^{-1}, 25^{\circ} \mathrm{C}$ temperature of the ambient air with $60 \%$ $\mathrm{RH}$. a flow rate of water for generating steam of $0.65 \mathrm{~mL}$ nin $^{-1}$. and a $110^{\circ} \mathrm{C}$ steam temperature. Water-absorbed particles can be impacted efficiently on the inner surface of the helix coil due to both an inertial force, enhanced by the increase in aerosol mass, and a centrifugal force. caused by movement through the curvature. As a result. the particles experience not only size growth, but also continuous collection in it. This is quite different from other particle collection sections in previous semicontinuous measurement systents. In the previous studies. the particle collection apparatuses were generally composed of a size growth chamber and particle collection device such as a cooled SS maze. a cyclone. or a single jet impactor. ${ }^{11-12.14 .19}$ As soon as particles were collected on the inner surface of the helix coil collector. the liquid samples were washed out rapidly and continuously with a strean of air to the outlet; their residence time was roughly $0.08-0.1 \mathrm{~s}$. Khlystov et al. (1995) reported that even if the supersaturation of water vapor is only $10 \%$. a residence time inside the mixing reservoir of about $\sim 0.1 \mathrm{~s}$ is still sufficient for particles of $19 \mathrm{~nm}$ dry diameter to grow to $1 \mu \mathrm{m}$ droplets.

The liquid samples were drained out after separation from the air stream in air/liquid separator and introduced into an online ion chromatography (IC) system. In air/liquid separator (Fig. 2c). the distance between the end of the outlet tube (Pyrex glass. $2 \mathrm{~mm}$ i.d.) and the wall surface was about $1 \mathrm{~mm}$ and the liquid samples were impacted on the wall surface. It was designed to minimize the loss of liquid droplets due to 
(a) mixing part

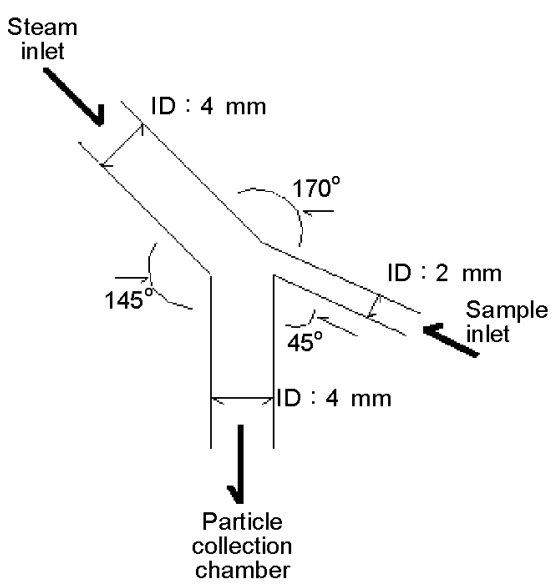

(b) particle collection chamber

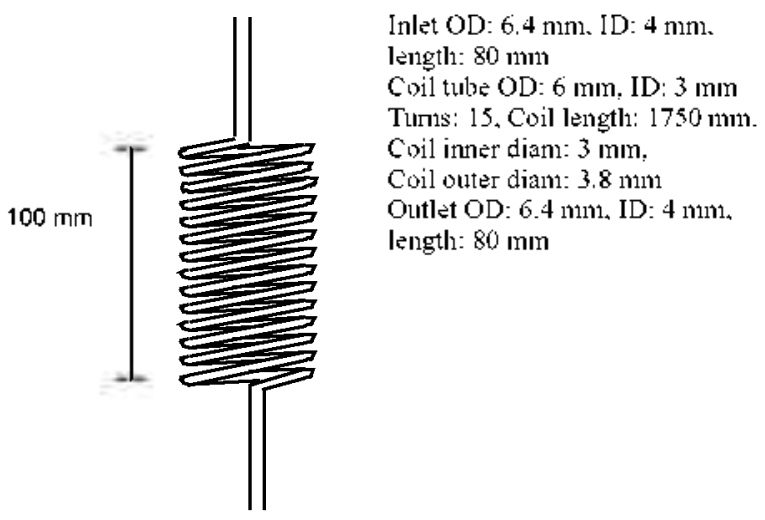

(c) air/liquid separator

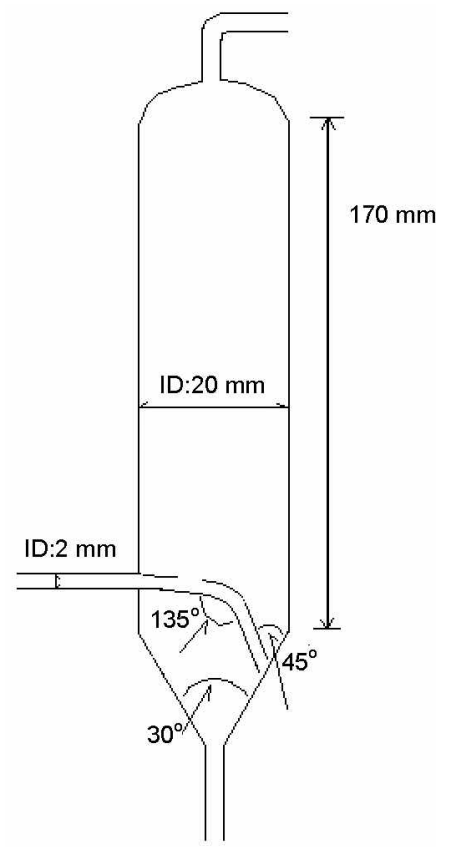

Figure 2. Details of the particle collection section: (a) mising part (b) particle collection chamber (c) air/liquid separator.

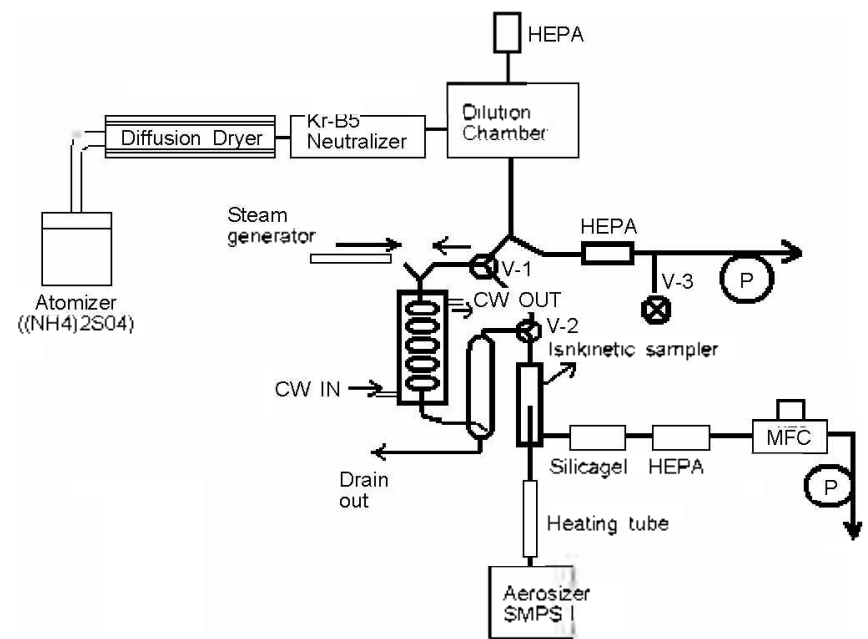

Figure 3. Schematic diagram of particle collection efficiency experiment (HEPA; HEPA filter, SMPS; Scanning Mobility Particle Sizer. DMA:TSI 3080 and CPC 3022. Aerosizer. API Inc.. Model Mach II. MFC; mass flow controller, $P$; Air pump, V-1,2,3; 3-way valve, $C W$; Cooling water $\mathrm{j}$.

bounce-off on the glass wall surface and was intended to sample at the EPA standard sample flow rate of $16.7 \mathrm{~L} \mathrm{~min}^{-1}$. All solutions were pumped through Teflon tubing (PTFE Microbore. ID: $0.022^{\prime \prime}$. OD: 0.042") using a low-flow and highaccuracy multichanuel peristaltic pump (ISMATIC. A-9560122).

Analytical system. The liquid samples were analyzed by two ion chromatography (IC) systems. Each IC system consisted of an automated time-controlled valve, set up with a sample loop, an analytical colunu. and a conductivity detector. The automated time-controlled valve (Rheodyne fluid processor Part No. 2320785C) was used to load liquid samples to the sample loops $(500 \mu \mathrm{L})$ and then to inject them on to two analytical colunins. Sample loops were entployed for IC injection due to their simplicity and stability during field operations. In contrast concentrator columns have been used in other techniques. ${ }^{14.19}$ Cations were analy zed using a Shodex column ( $4 \mathrm{~mm} \times 150 \mathrm{~mm}$. YK-421) of a non-suppressor tipe. The analy ses were carried out with an isocratic elution method using an eluent of a mixture of $2 \mathrm{mM} \mathrm{HNO}_{3}$ and $0.75 \mathrm{mM}$ dipicolinic acid (PDCA). at a flow rate of $1.0 \mathrm{~mL} \mathrm{~min}^{-1}$. Anions were analyzed on a Dionex ASl $+240 \mathrm{~mm}$ column, a chenicalsuppressor type ( $50 \mathrm{mN} \mathrm{H}_{2} \mathrm{SO}_{4}$. flow rate $\left.1.4 \mathrm{~mL} \mathrm{~min}^{-1}\right)$. This column was also operated with an isocratic elution method using an eluent of a mixture of $3.5 \mathrm{mM} \mathrm{Na} 2 \mathrm{CO}_{3}$ and $1 \mathrm{mM}$ $\mathrm{NaHCO}_{3}$. at a flow rate of $1.2 \mathrm{~mL} \mathrm{~min}{ }^{-1}$. The liquid samples were introduced into the anion and cation sample loops in two sis-way ports at a flow rate $0.17 \mathrm{~mL} \mathrm{~min}^{-1}$ (ISMATIC. A95601-22), while pre-injected liquid samples were analyzed by the two IC systems. When the liquid samples were loaded into two sample loops, extra liquid samples with air bubbles were arranged to bypass through a simple de-bubbler. Approximately 20 min was required for a liquid sample to be quantified completely. due to the analytical time of the IC system. Peak areas were integrated with a NDA 401 Network Data Acquisition (Yullin Technology. Korea). 
Calibrations were conducted after intensive field measurements over 2 weeks using standard solutions that were diluted from stock solutions (Exaxol Chemical Corporation. 05l11B). In order to determine the air volume mixing ratios of aerosol components. it was crucial to accurately measure the flow rate of the air sample and the liquid volume for ambient aerosols dissolved in a particle collection section. $\mathrm{LiBr}$ was spiked into the distilled water used for steam generation to precisely calculate the liquid volume. ${ }^{19}$ The flow rate of air samples was controlled using a rotameter calibrated in the laboratory' with a dry gas meter (Bios DryCal) prior to ambient air sampling.

Particle collection efficiency setup. Figure 3 shows a schematic diagram of the particle collection efficiency (PCE) setup. The size of tested aerosols ranged from 0.05 to $3.5 \mu \mathrm{m}$ in aerody namic diameter. As a perfonnance test. a number of collection efficiencies expenments were conducted for vanous types of aerosols such as $\left(\mathrm{NH}_{4}\right)_{2} \mathrm{SO}_{4} \mathrm{NaCl} \mathrm{NH}_{4} \mathrm{HSO}_{4}$ and $\mathrm{NH}_{4} \mathrm{NO}_{3}$. The test aerosols were generated by nebulizing the corresponding test aerosol liquid solutions using a Ventuntype nebulizer with dry. particle-free zero air, followed by their passage through a $\mathrm{Kr}-85$ charge neutralizer. The concentrations of test aerosols are dependent on the concentration of the solution as well as the flow rate of carrier and dilution air. The dilution chamber allowed the mixing of test aerosols and particle-free air. The chemicals were of reagent grade (Merck) and deionized water was used for preparing solutions. For collection efficiency of test aerosols. the size distributions of the particles at the inlet and outlet of the particle collection section were measured by a SMPS system (Scanning Mobility Particle Sizer. DMA:TSI 3080 and CPC 3022) and an Aerosizer (API Inc.. Model Mach II). The SMPS was used to measure the size distribution of small particles $(<0.5 \mu \mathrm{m})$ and the Aerosizer for larger particles $(>0.5 \mu \mathrm{m})$.
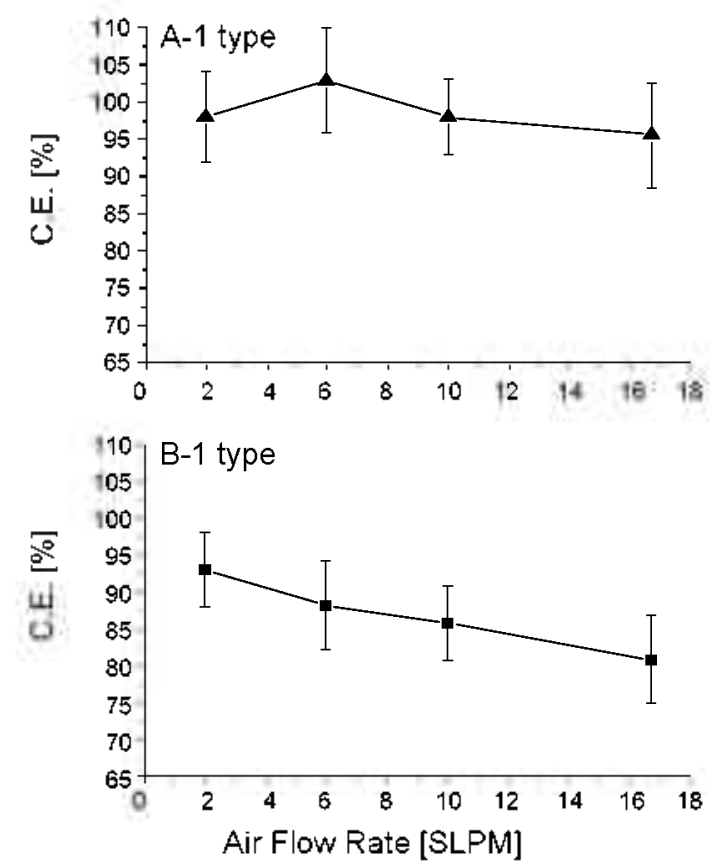

\section{Experimental Results}

Design of the airfliquid separator. Figure 4 illustrates the two types of air/liquid separator tested and Figure 5 indicates the collection efficiency $(\beta)$ of the steam injected into the particle collection section, calculated as follows:

$$
C E(\beta) \text { of steam }=Q_{2} / Q_{1} \times 100(\%)
$$

where $Q_{1}$ is the water flow rate for generating the steam injected to the inlet of the Yconnector $\left(0.65 \mathrm{~mL} \mathrm{~min}^{-1}\right)$ and $\mathrm{Q}_{2}$ is
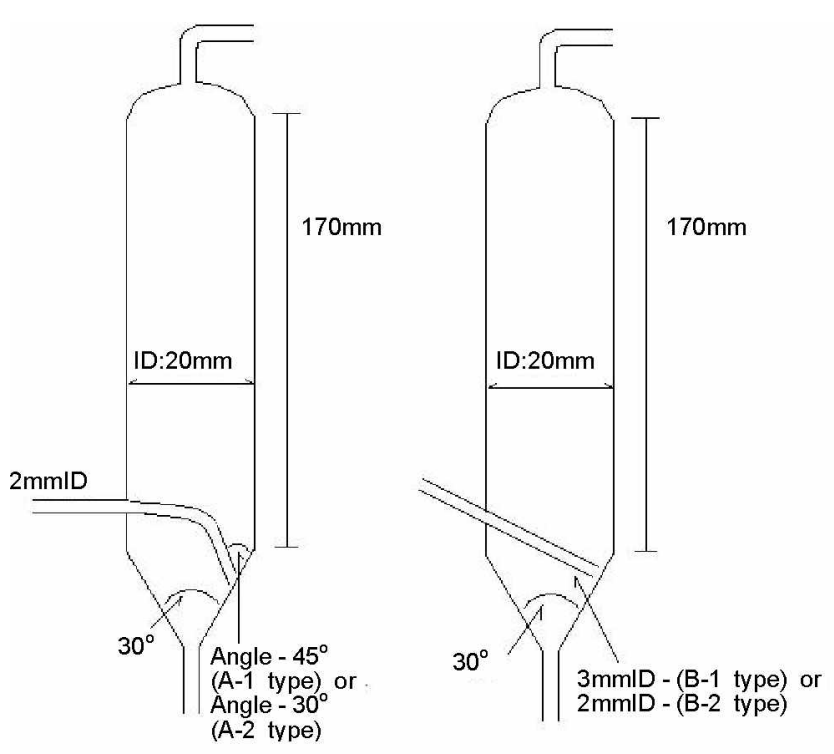

Figure 4. Various types of air/liquid separator (A-1, A-2, B-1, and B-2).
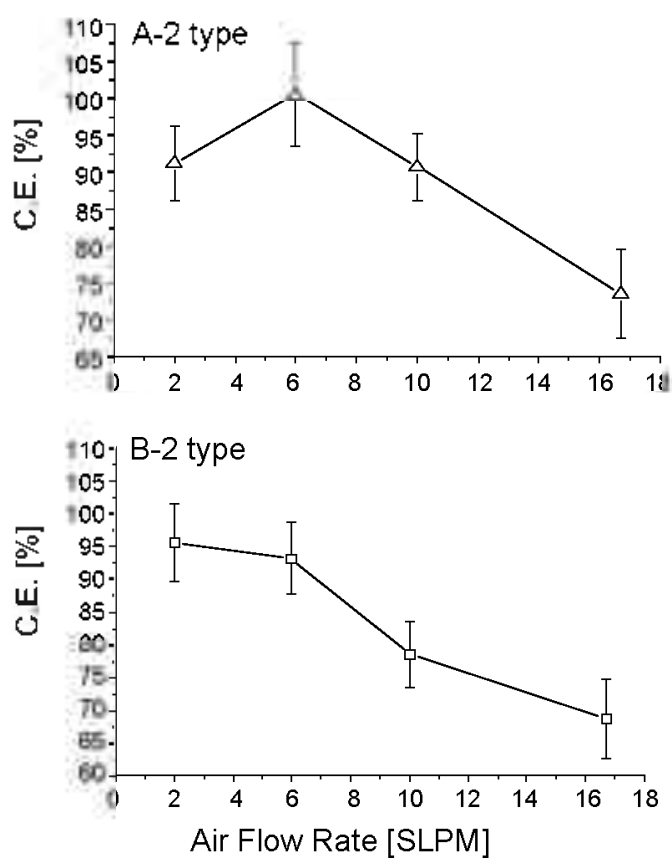

Figure 5. Collection efficiencies (p) of steams injected to particle collection section ( $\boldsymbol{\Delta}$ :A-1 type, A:A-2 type, -: B-1 type, a: B-2 type). Enor bars mean one standard deviation $(n=5)$. 

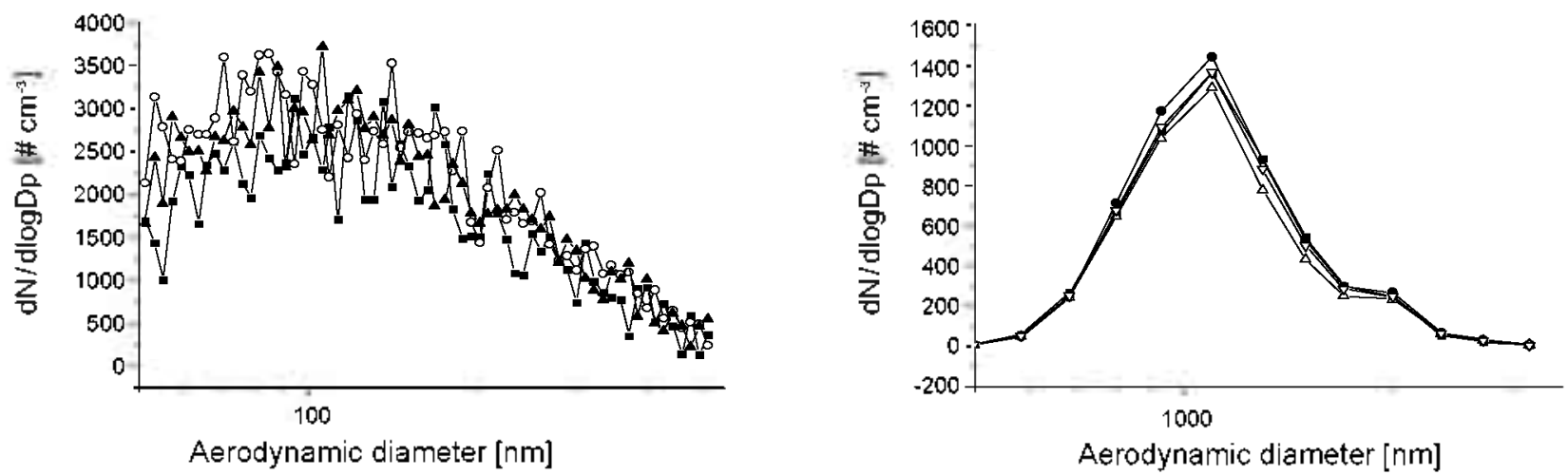

Figure 6. Size distributions of $\left(\mathrm{NH}_{4}\right)_{2} \mathrm{SO}_{4}$ tested nn the range of $50-500 \mathrm{~nm}$ and over $500 \mathrm{~nm}$ in alerodynamic particle diameter.

the flow rate of liquids drained out in the air/liquid separator.

Figure 5 showed that $\beta$ was similar at low air sample flow rates. but different at higher flow rates. depending on the design of the air/liquid separator. Except for the A-1 type, $\beta$ decreased rapidly as the flow rate of the air sample increased. This decrease was mainly attributable to the combined effects of bounce-off on the wall surface due to the impaction of liquid droplets. and the flow patterns of liquid droplets in the separator. In particular. these effects were more important at higher flow rates of air than a low flow rate. When liquid droplets were strongly impacted on the inner wall surface in the airfliquid separator they bounced and then scattered. rather than draining out to the outlet. Consequently, this may have led to a decreased collection of steam in a given air/ liquid separator. Furthermore. the liquid droplets after impaction could be advected with an air sample as the sample flow rate increased. especially when it was larger than $10 \mathrm{~L} \mathrm{~min}^{-1}$. Thus. these effects must be considered in increasing $\beta$ and an appropriate air/liquid separator design is required. especially at a high sample flow rate.

The results of this study indicated that $\beta$ was larger than $95 \%$ in the A-I design at $16.7 \mathrm{~L} \mathrm{~min}^{-1}$ (Fig. 5). The angle of the injection tube and the sliding surface in air/liquid separator was roughly $45^{\circ}$ in the A-l design (see Fig. 4). However, the results were not good when the A-2 design was applied, where the angle was about $30^{\circ}$, and $\beta$ was less than $75 \%$ at $16.7 \mathrm{~L}$ $\mathrm{min}^{-1}$. Although the bounce effect in the A-2 design was lower than in the A-1 design. as the sample flow rate increased, more liquid samples after impaction had a tendency to be transported together with the air sample. The bounce was greater in the $\mathrm{B}$ type due to its higher angle (i.e. $90^{\circ}$ ). When the response of the separator to the inner diameter was tested by using of 2 and $3 \mathrm{~mm}$ i.d. tube. liquid loss was almost entirely ascribed to the bounce effects. The $\beta$ of the $B-1$ design ( $3 \mathrm{~mm}$ i.d. outlet tube) was better than that of the B-2 design ( 2 mm i.d. outlet tube) due to the smaller linear velocity:

Particle collection efficiencies. At a sample flow rate of $16.7 \mathrm{~L} \mathrm{~min}{ }^{.1}$. water flow rates for generating steam and number of coil turns of a particle collector were determined sy stematically through $\mathrm{PCE}$ tests to optimize the performance of the particle collection section. PCE tests were carnied out by modifying number of coil turns ( 8 tums, 10 tums, 13 turns. and 15 turns) and the flow rates $\left(0.17 \mathrm{~nL}^{-1} \mathrm{~min}^{-1} .0 .35 \mathrm{~mL} \mathrm{nin}^{-1}, 0.65\right.$ $\mathrm{mL} \mathrm{min}^{-1}$. and $1.00 \mathrm{~mL} \mathrm{~min}^{-1}$ ) of water injected for steam generation. In these experiments. the A-l design of the air/ liquid separator was used. as described above. PCEs of aerosols with diameters in the range of 50-500 $\mathrm{mm}$ and over $500 \mathrm{~nm}$ were calculated as follows:

PCEs $=1-\sum C_{\text {cut }} / \sum \mathrm{C}_{\text {un }} \times 100(\%)$

where $\mathrm{C}_{\mathrm{our}}$ and $\mathrm{C}_{\mathrm{jn}}$ are the number concentrations of aerosol particles at the outlet and inlet of particle collection section. measured using a SMPS and an Aerosizer.

Figure 6 shows the size distributions of $\left(\mathrm{NH}_{4}\right)_{2} \mathrm{SO}_{4}$ tested in the range of $50-500 \mathrm{~nm}$ and over $500 \mathrm{~nm}$ upstream of the particle collection section. Figure 7 indicates size-resolved PCEs of the particle collection section in the range of 50-500 nni aerody nanic particle diameters at various water flow rates for steam generation and coil turns. The absolute uncertainties $\left(S_{y}\right)$ of PCEs were calculated according to error propagation in multiplication or division as follows $(n=3)$ :

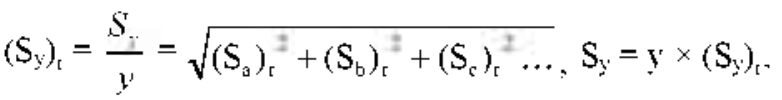

where $\left(S_{y}\right)$, is the relative uncertainty and standard deviation divided by the mean value. ${ }^{\wedge}$ The resulting absolute uncertainties were found to be roughly of a magnitude of $\pm 10 \%$.

The results indicated that PCEs increased generally with an increased water flow rate for generating steam when the coil turns of a particle collector were constant. The PCEs were also observed to increase with the increasing number of coil turns at a constant flow rate for steam generation. These results were ascribed to the increased relative humidity and residence time, up to $-0.1 \mathrm{~s}$. Figure 7 also shows the gradual increase in PCEs with increasing test aerosol size. The PCEs were 20$40 \%$ and $30-60 \%$ at water flow rates for steam generation of 0.17 and $0.35 \mathrm{~mL} \mathrm{m^{-1 }}$, respectively. They increased up to $\sim 80 \%$ with a particle collector of 15 turns. when the water flow rate for stean generation was $0.65 \mathrm{~mL} \mathrm{~min}{ }^{-1}$. As the water flow rate increased from $0.65 \mathrm{~mL} \mathrm{~min}$ to $^{-1} 1.00 \mathrm{~mL} \mathrm{~min}{ }^{-1}$, the PCEs clearly increased from $40 \%$ to $60 \%$ with a particle collector of 8 turns, but were largely in the range of $70-80 \%$. 
(d)

(c)

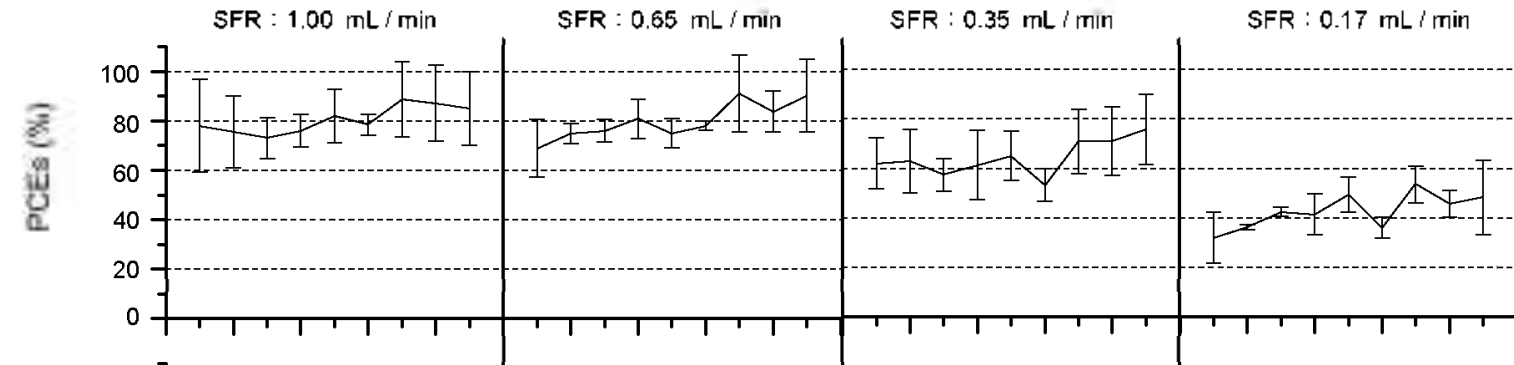

(b)

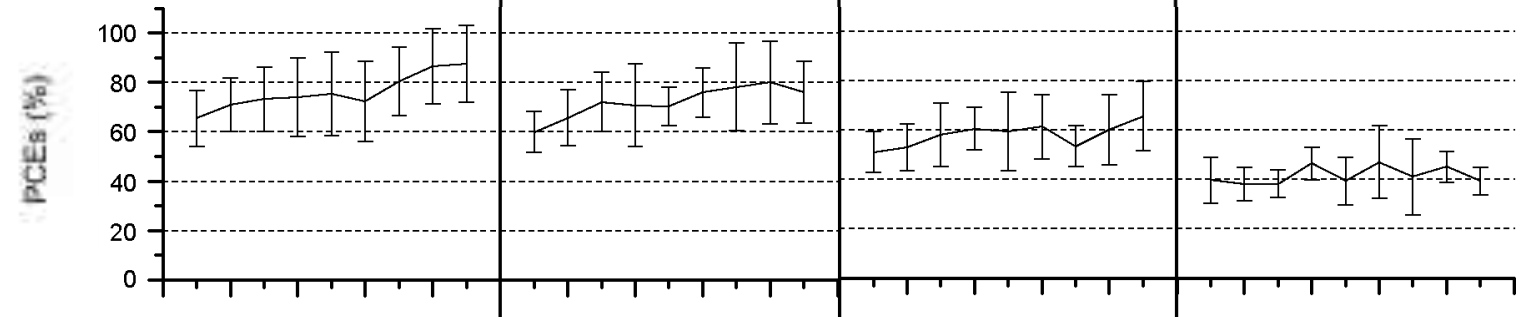

(a)

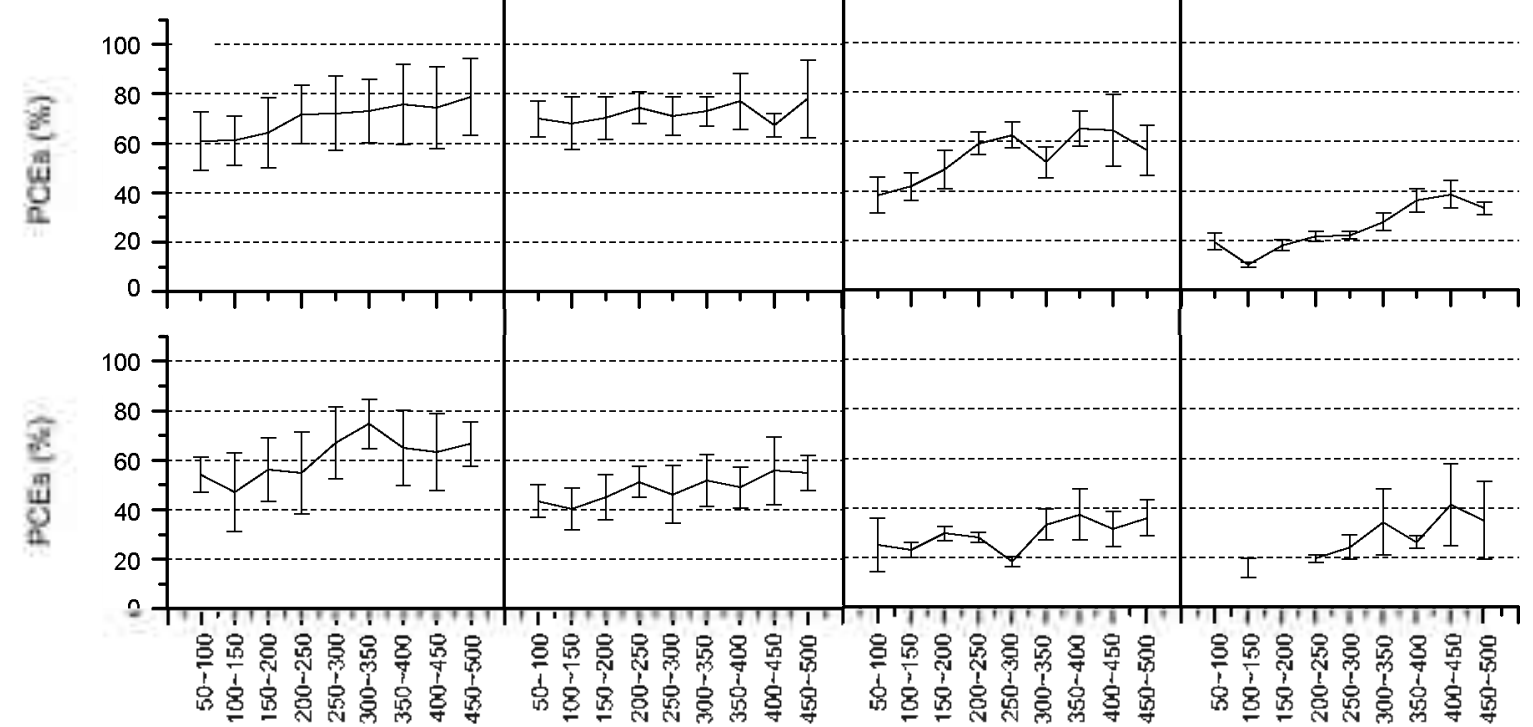

Aerodynamic diameter $(\mathrm{nm})$

Figure 7. Size-resolved PCEs $(\%)$ of $\left(\mathrm{NH}_{4}\right)_{2} \mathrm{SO}_{4}$ in the range of $50-500 \mathrm{~mm}$ in aerodynamic particle diameter in the particle collection section according to DW flow rates for steam generation (SFR), measured by a SMPS (Scanning mobility particle sizer. DMA: TSI Mode 3080 and CPC: TSI Model 3020 ). (a: 8 tums, b; 10 tums, c; 13 tums, d; 15 tunis, air flow rate: $2 \mathrm{~L} \mathrm{~min}^{.1}$ ). Error bars indicates the absolute uncertainties of the PCEs $(\%)$.

with particle collectors of 10-15 turns.

In the range over $500 \mathrm{~nm}$, the results were $50 \%$ and $90 \%$ at the air sample flow rate of $2 \mathrm{~L} \mathrm{~min}^{-1}$ and at the water flow rate of $0.17 \mathrm{~mL} \mathrm{~min}^{-1}$ for steam generation (see Fig. 8). The PCEs enhanced steadily up to $100 \%$ as the water flow rate increased from 0.17 to $1.00 \mathrm{~mL} \mathrm{~min}{ }^{-1}$ at the sample flow rates lower than $6 \mathrm{~L} \mathrm{~min}^{-1}$. Furthermore. the PCEs approached almost $100 \%$ when the sample flow rate was larger than $6 \mathrm{~L} \mathrm{~min}^{.1}$. in the range of $0.17-1.00 \mathrm{~mL} \mathrm{~min}{ }^{-1}$ for the water flow rate. The risk of a liquid droplet's loss on the inner surface of particle collector due to turbulent deposition. was expected to increase as the Reynolds numbers increase at higher air sample flow rates. $29^{\circ}$

From the experimental results of PCEs above and the sensitivity of the system, a 15-turn coil particle collector and a steam flow rate of $0.65 \mathrm{~mL} \mathrm{~min} \mathrm{~m}^{-1}$ were found to be optimal. Table 1 summarizes the PCEs of $\left(\mathrm{NH}_{4}\right)_{2} \mathrm{SO}_{4}, \mathrm{NH}_{4} \mathrm{NO}_{3}, \mathrm{NaCl}$,
Table 1. The PCEs (\%) for various test aerosols in particle collection section at $16.7 \mathrm{~L} \mathrm{~min}^{-1}$ (coil tums, 15 tums, steam flow rate; $0.65 \mathrm{~mL}$ $\min ^{-1}$ )

\begin{tabular}{|c|c|c|c|}
\hline & $\begin{array}{l}\text { Number Con. } \\
\left(\# \mathrm{~cm}^{-3}\right)\end{array}$ & $\begin{array}{c}\text { PCEs }(\%) \\
(\text { diam }>500 \mathrm{~nm})\end{array}$ & $\begin{array}{c}\text { PCEs }(\%) \\
\text { (diam }<500 \mathrm{~nm})\end{array}$ \\
\hline \multirow{3}{*}{$\mathrm{NaCl}$} & 63000 & $\sim 100$ & 90 \\
\hline & 300000 & $\sim 100$ & 81 \\
\hline & 780000 & -100 & 57 \\
\hline \multirow{3}{*}{$\left(\mathrm{NH}_{4}\right)_{2} \mathrm{SO}_{4}$} & 80000 & -100 & 91 \\
\hline & 350000 & -100 & 80 \\
\hline & 900000 & $\sim 100$ & 60 \\
\hline \multirow{3}{*}{$\mathrm{NH}_{4} \mathrm{HSO}_{4}$} & 80000 & -100 & 88 \\
\hline & 300000 & $\sim 100$ & 64 \\
\hline & 900000 & -100 & 47 \\
\hline \multirow{2}{*}{$\mathrm{NH}_{4} \mathrm{NO}_{3}$} & 70000 & -100 & 88 \\
\hline & 350000 & -100 & 85 \\
\hline
\end{tabular}


Table 2. The Reproducibilities (RSD, \%), Linearities $\left(\mathrm{r}^{2}\right.$ ), and Limits of Detection (LOD) of semicontinuous ion measurement system during field measurement period.

\begin{tabular}{|c|c|c|c|c|}
\hline $\mathrm{NO}$ & Components & Reproducibility (RSD,$\%$ ) & Linearity $\left(r^{2}\right)$ & $\operatorname{LOD}^{b}\left(\mu \mathrm{m}^{-3}\right)$ \\
\hline 1 & $\mathrm{Cl}^{-}$ & 11.4 at $10 \mathrm{ppb}$ & $0.92 \sim 0.99$ & $0.06 \cdots 0.25$ \\
\hline 2 & $\mathrm{NO}_{2}^{-}$ & 16.0 at $10 \mathrm{ppb}$ & $0.94 \sim 0.99$ & $0.06-0.25$ \\
\hline 3 & $\mathrm{NO}_{3}^{-}$ & 24.0 at $5 \mathrm{ppb}$ & $0.94 \sim 0.99$ & $0.06-0.25$ \\
\hline 4 & $\mathrm{SO}_{4}{ }^{2-}$ & 5.0 at $15 \mathrm{ppb}$ & $0.98 \sim 0.99$ & $006-0.25$ \\
\hline 5 & $\mathrm{Na}^{+}$ & 4.0 at $20 \mathrm{ppb}$ & $0.99 \sim 0.99$ & $0.25-0.50$ \\
\hline 6 & $\mathrm{NH}_{+}^{+}$ & 4.5 at $40 \mathrm{ppb}$ & $0.98 \sim 0.99$ & $0.24-0.50$ \\
\hline 7 & $\mathrm{~K}^{-}$ & 14.3 at $20 \mathrm{ppb}$ & $0.98 \sim 0.99$ & $0.13-0.28$ \\
\hline 8 & $\mathrm{Mg}^{2+}$ & 15.1 at $20 \mathrm{ppb}$ & $0.97 \sim 0.99$ & -0.20 \\
\hline 9 & $\mathrm{Ca}^{2+}$ & 25.0 at $10 \mathrm{ppb}$ & $0.97 \sim 0.99$ & -0.20 \\
\hline
\end{tabular}

${ }^{a}$ Relatice standard deciation (standard deviation mean $\quad 100$ ) ${ }^{b} \mathrm{LOD}$ was calculated as the three times of noise level of system blank at $990 \%$ confidence level

(a)

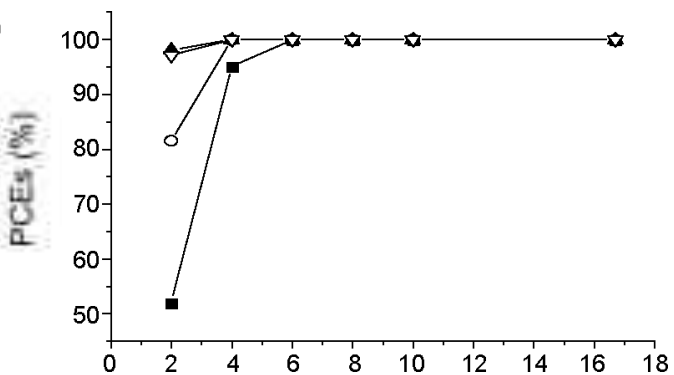

(b)

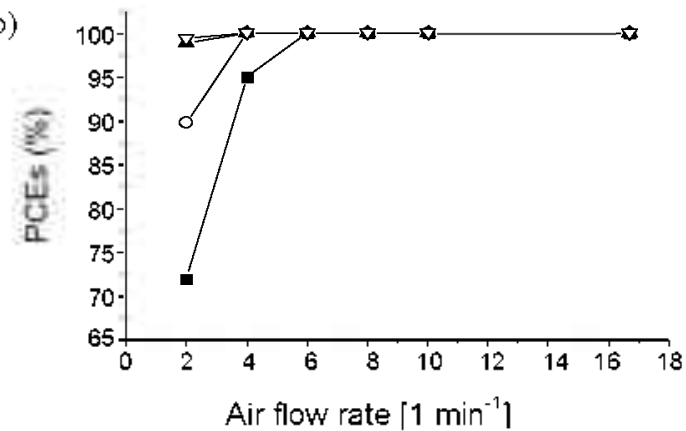

(c)

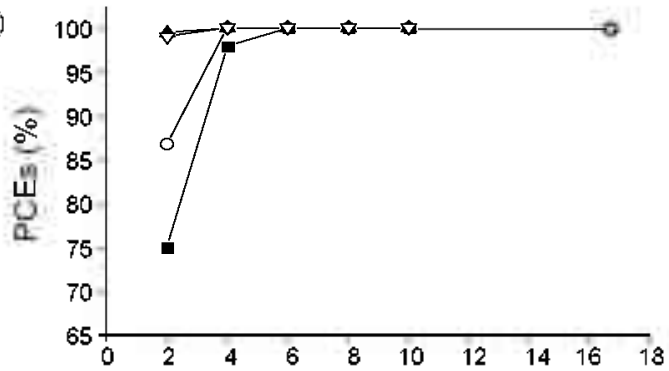

(d)

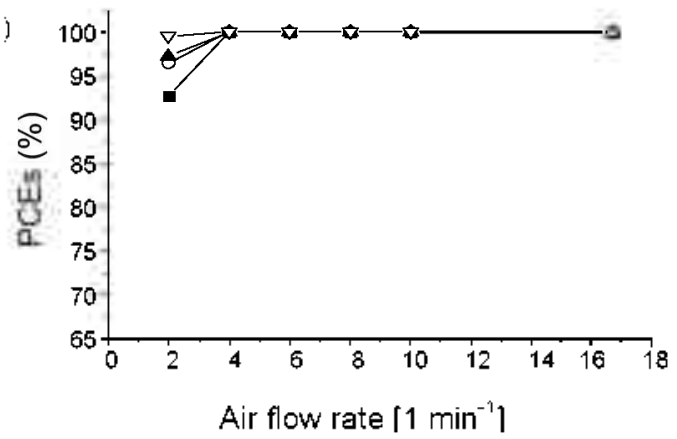

Figure 8. PCEs (\%) of $\left(\mathrm{NH}_{4}\right)_{2} \mathrm{SO}_{4}$ in the Particle collection section (particle diam $>500 \mathrm{~nm}$ ) (water flow rates for steam generation: a: $0.17 \mathrm{~mL}$ $\mathrm{min}^{-1}, 0.35 \mathrm{~mL} \mathrm{~min}^{-1}, \boldsymbol{\Delta}: 0.65 \mathrm{~mL} \mathrm{~min}^{-1}, \nabla: 1.00 \mathrm{~mL} \mathrm{~min}^{-1}$ ) (a) 8 tums, (b) 10 turns, (c) 13 tums, (d) 15 tums.

and $\mathrm{NH}_{4} \mathrm{HSO}_{4}$ at various concentrations. The results indicated that the PCEs were almost $100 \%$ in the range over $500 \mathrm{~nm}$ at different concentrations. However, the PCEs were 50-90\% for particles in the range of 50-500 nm. depending on types of test aerosols and their number concentrations. In particular. they decreased gradually as the concentrations of test aerosols increased: the higher the number concentration of test aerosols was, the more difficult it was to induce growth of the test aerosols at constant steam flow rates. In the case of test aerosols less than $500 \mathrm{~nm}$, the lowest number concentrations tested were comparable to real urban areas. such as Seoul. Korea. ${ }^{3(-31}$ Thus. the PCEs (88-91\%) of these concentration levels were meaningful in terms of the field campaign.

Field obsenvations of $\mathbf{P} \mathbf{M}_{2.5}$ soluble species. A field campaign was conducted at an atmospheric observatory located on Mt. Muak. on January 11-24. 2006. at Yonsei University (sea level: $\sim 250 \mathrm{~m}$ ) in Seoul. A major road was adjacent to the measurement site. $30 \mathrm{~m}$ to the northeast. The $\mathrm{PM}_{2.5}$ cyclone of measurement system was set up on the roof of trailer (4 m above the ground surface). The denuder systems were replaced every $3-4$ days. The reproducibility (RSD, \%), linearity $\left(\mathrm{r}^{2}\right)$, and limits of detection (LOD) of system in the field experiment are shown in Table 2.

The reliability of analytical data was examined by the ion charge balance theory of soluble inorganic species in aerosol particles. According to this theory. the sun of the cation equivalent concentrations should be identical to the sum of the anion equivalent concentrations if all soluble ions in aerosol particles are accurately analyzed. Thus. this theory can be used to verify accurate determination of the major ionic species. Figure 9 shows scattergrams between the sum of the cation equivalent concentrations and the sum of the anion equivalent concentrations. According to the result of the regression analy sis. the Pearson correlation coefficient was 0.87 with the uncertainties of $95 \%$ confidence intervals. The slope (1.3) of the regression line indicated that the sum of the cation 


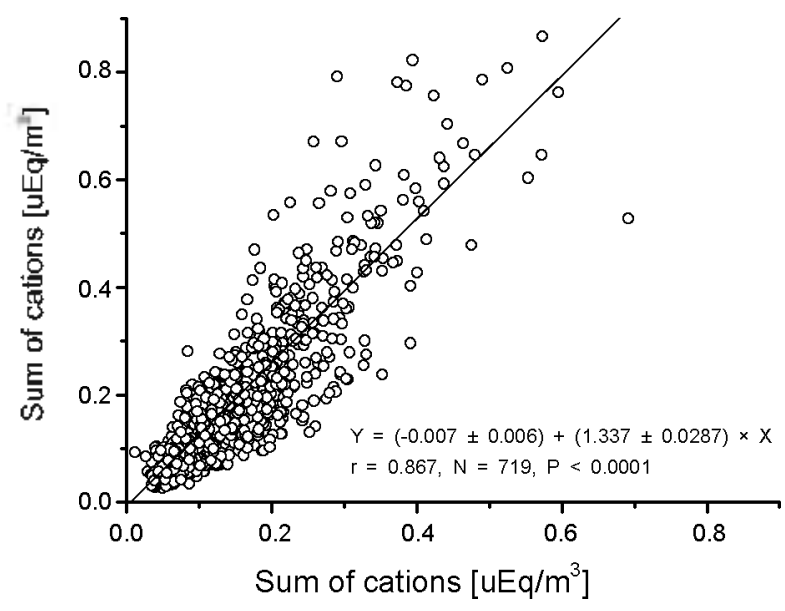

Figure 9. Ion charge balance for the measured inorganic species in $\mathrm{PM}_{2}$. . Cations: $\mathrm{Ca}^{2-}+\mathrm{Mg}^{2-}+\mathrm{K}^{-}+\mathrm{Na}^{-}+\mathrm{NH}_{4}^{+}$, Anions: $\mathrm{Cl}^{-}+\mathrm{NO}_{3}{ }^{-}$ $+\mathrm{SO}_{4}^{2}$.
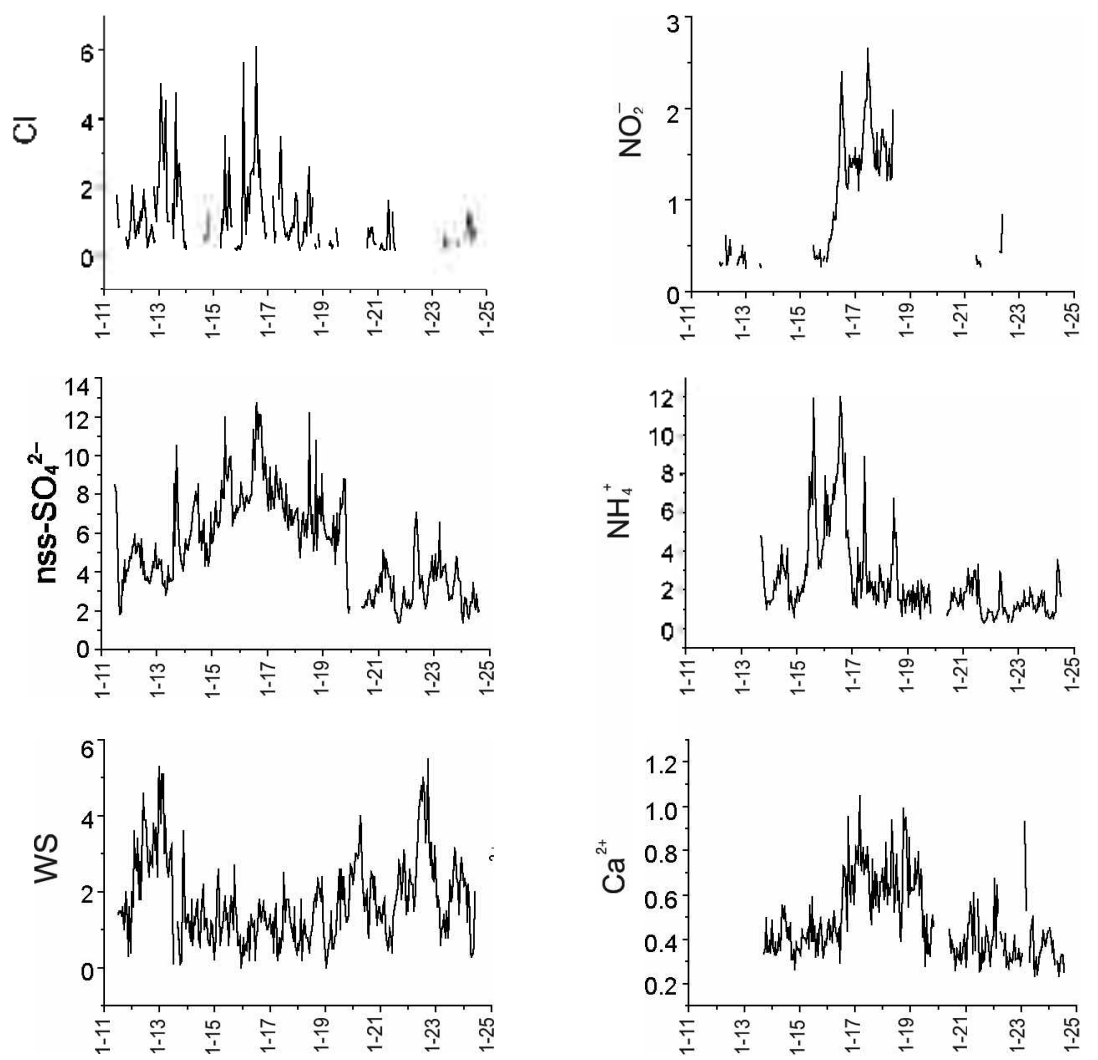

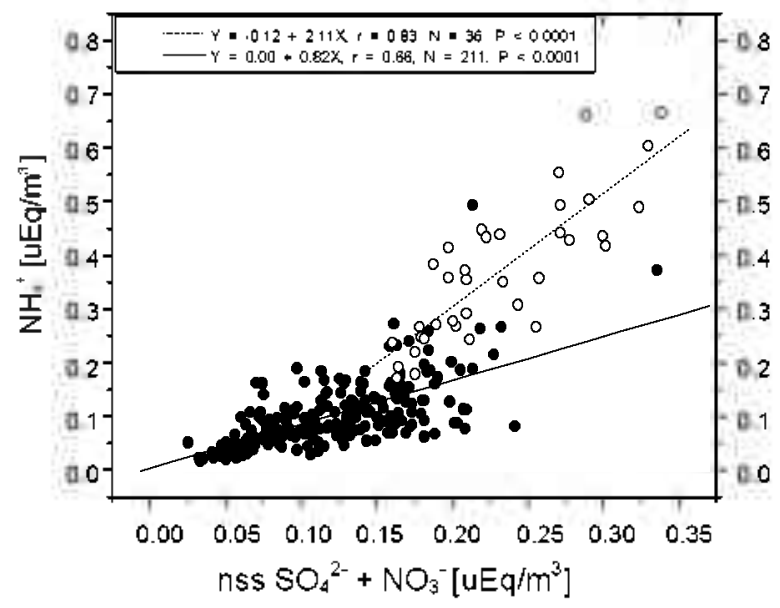

Figure 10. The scattergrams between $\mathrm{NH}_{4}^{+}$and nss- $\mathrm{SO}_{4}{ }^{2-}+\mathrm{NO}_{3}{ }^{-}$. (.. Tan $15,10: 00$ - Tan $16,18: 00 \cdot$ others).
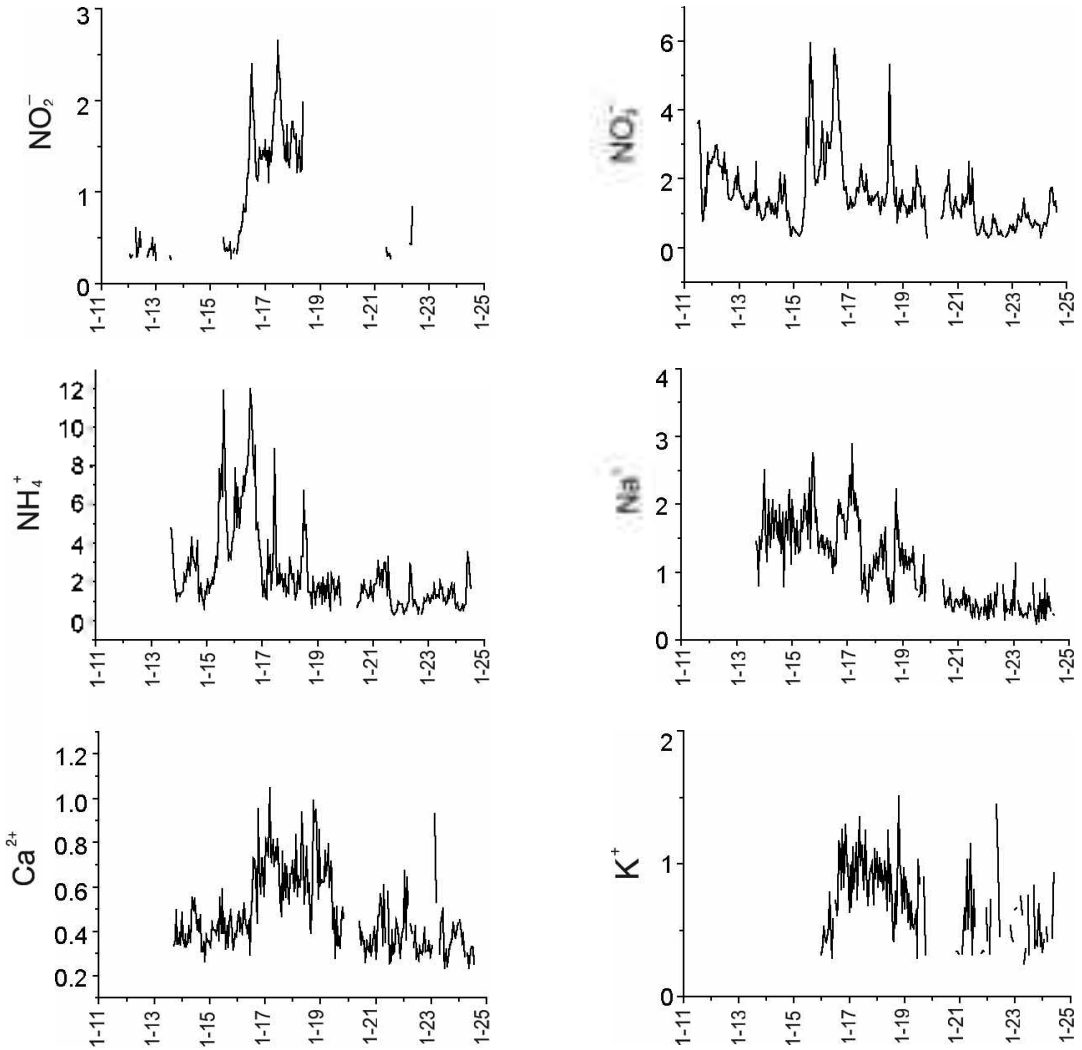

Figure 11. Time series of inorganic species in $\mathrm{PM}_{2 . s}$ and wind speed (WS) measured during field campaigns (unit of inorganic species: $\mu g \mathrm{~m}^{-3}$, unit of WS: $m$ sec $^{-1}$, Rainfall event: $20: 00 \mathrm{~h}$, Jan. $12 \sim 1600 \mathrm{~h}$, Jan. 13 , the maximum raintall: $5 \mathrm{~mm}$ on 0600 , Tan. 13). The anion eluent delivery pump got out of order on $0000 \sim 1000 \mathrm{~h}$, Jan 20 .

equivalent concentrations was somew hat larger than that of the anion equivalent concentrations. There may be several possible reasons why we underestimated anion species and overestimated cation species. The contributions of organic anions such as $\mathrm{HCOO}^{-}$and $\mathrm{CH}_{3} \mathrm{COO}^{-}$may be small because their concentrations were even lower than those of acidic anions, such as $\mathrm{SO}_{4}{ }^{-}$and $\mathrm{NO}_{3}{ }^{-}$. The contribution of $\mathrm{CO}_{3}{ }^{--}$. which was not determined in IC. was also unlikely to be significant. due to its dominant existence of $\mathrm{CaCO}_{3}$ in the coarse mode $(2.5<$ diameter $<10 \mu \mathrm{m})$ of aerosols. ${ }^{32 \cdot 33}$ The determinations of $\mathrm{Na}^{-}$and $\mathrm{NH}_{4}{ }^{-}$with uncertainties took placed frequently owing to the overlap of the two peaks in IC chromatogrants. Figure 10 indicates that the slope of the regression line between $\mathrm{NH}_{4}{ }^{-}$and $2 \mathrm{SO}_{4}{ }^{--}+\mathrm{NO}_{3}{ }^{-}$was $\sim 0.8$ in the low concentration ranges. but -2 in higher concentration ranges. Thus. $\mathrm{NH}_{4}{ }^{-}$in particular may be overestimated at higher concentration ranges. This may also contribute to bias the slope of the total data. 

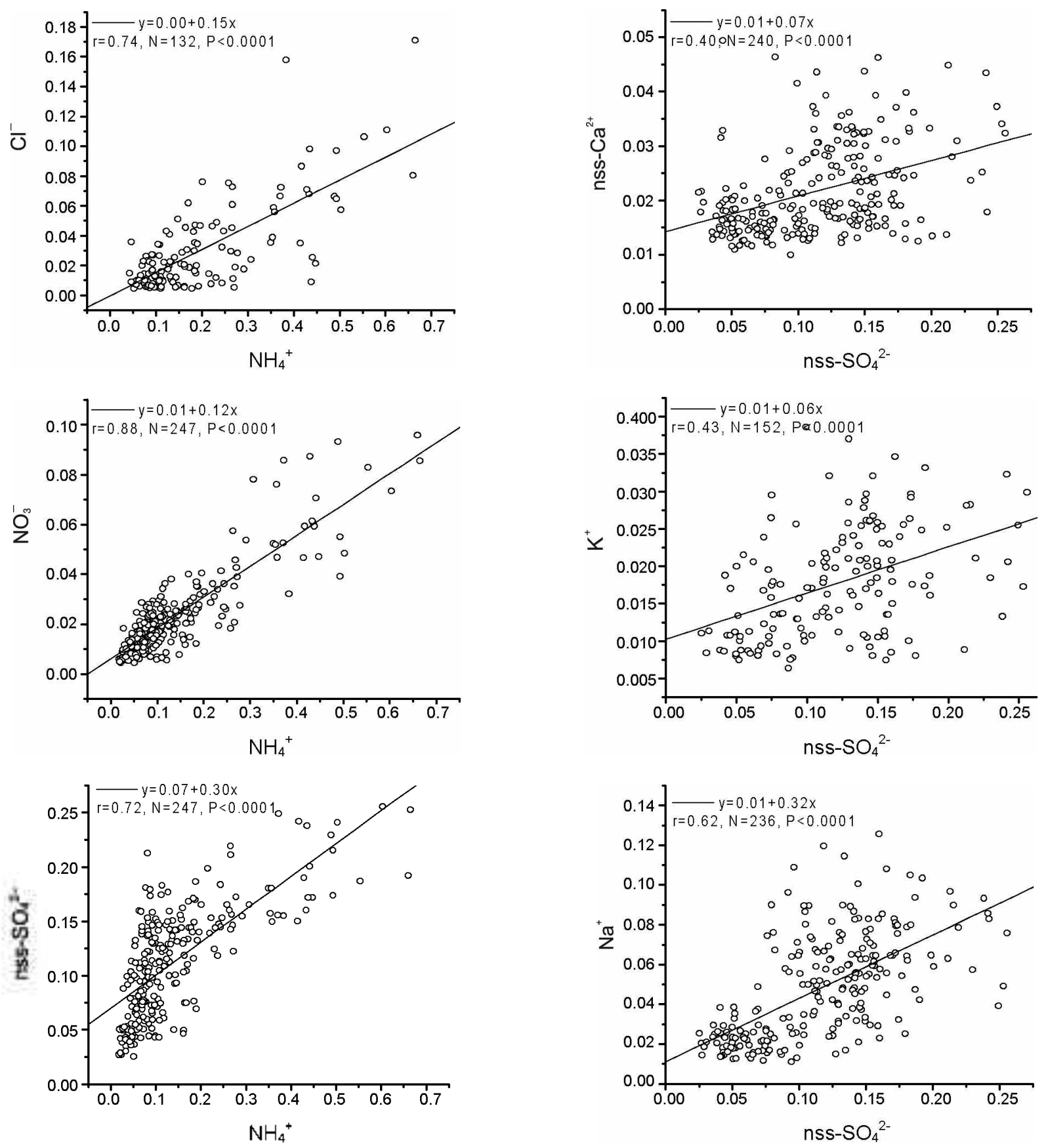

Figure 12. Scattergrams between major cationic species and anionic species (unit; $\mathrm{uEq}^{-{ }^{-3}}$ ).

Figure 11 illustrates the temporal variations in ionic species in $\mathrm{PM}_{3.5}$ and the wind speed (WS) during the measurement period. The concentrations of $\mathrm{NH}_{4}^{-} \cdot \mathrm{Na}^{+} \cdot \mathrm{K}^{+} \cdot \mathrm{Ca}^{3-} \cdot \mathrm{SO}_{4}{ }^{--} \cdot \mathrm{NO}_{3}^{-}$. $\mathrm{NO}_{2}^{-}$, and $\mathrm{Cl}^{-}$were $2.52 \pm 2.18$ ( \pm standard deviation). $1.09 \pm$ $0.61 .0 .70 \pm 0.33,0.48 \pm 0.17 .5 .37 \pm 2.46,1.53 \pm 1.02,0.98$ \pm 0.64 . and $1.04 \pm 0.98 \mu \mathrm{g} \mathrm{m} \mathrm{m}^{-3}$. respectively. Generally, the levels of ionic species in $\mathrm{PM}_{2}:$ remained relatively low until January 15 and increased steadily thereafter. In particular. the concentrations of $\mathrm{NH}_{4}{ }^{-}, \mathrm{SO}_{4}{ }^{--}$, and $\mathrm{NO}_{3}{ }^{-}$clearly began to increase from January 15 and those of $\mathrm{K}^{+}$. $\mathrm{NO}_{2}^{-}$. and $\mathrm{Ca}^{2-}$ increased from January 16 . Their concentrations again decreased in the late afternoon on January 19 and then remained low. Figure 11 indicates that the concentrations of anions and paired cations varied generally with similar trends. Figure 12 illustrates the relationslips between paired ions. Correlation coefficients indicated that the main forms of the compounds in $\mathrm{PM}_{2.5}$ were $\left(\mathrm{NH}_{4}\right)_{2} \mathrm{SO}_{4} . \mathrm{Na}_{2} \mathrm{SO}_{4} \mathrm{NH}_{4} \mathrm{Cl}$. and $\mathrm{NH}_{4} \mathrm{NO}_{3}$, but that some $\mathrm{K}_{2} \mathrm{SO}_{4}$ and $\mathrm{CaSO}_{4}$ were also present.

The distributions of the ionic species in $\mathrm{PM}_{2.5}$ are primarily influenced by photochenustry. themodynamics. and meteoro$\log y^{24 \cdot 25,24}$ The contribution of photochemical processing was expected to be minor because of the generally low temperature (maxinum temperature: $\sim 8^{\circ} \mathrm{C}$ ), low levels of photochemical oxidants (maximum levels of $\mathrm{O}_{2}: \sim 25 \mathrm{ppbv}$ ). and weak radiation in the daytime during the winter. The relationships between photochemical products (nss- $\mathrm{SO}_{4}{ }^{2-}$ and 

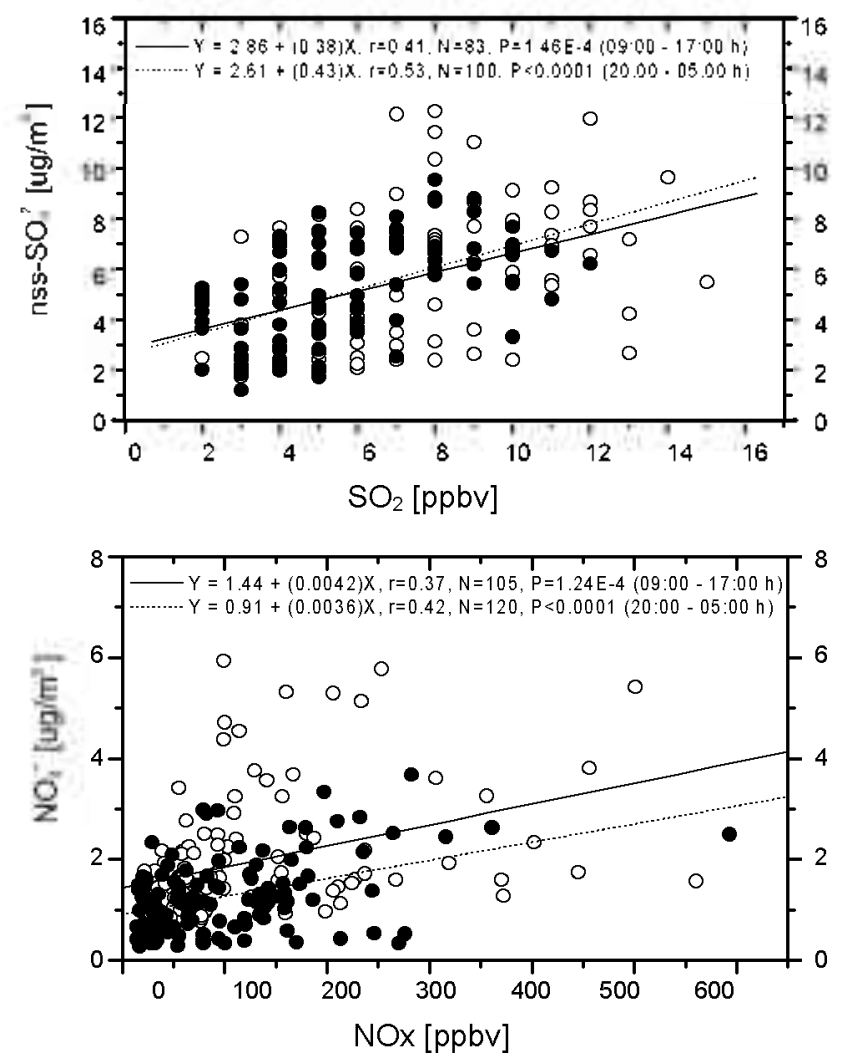

Figure 13. The scattergrams between secondary species (nss-SO ${ }_{+}^{-}$, $\mathrm{NO}_{3}{ }^{-}$) in tine particles and precursor gases ( $\mathrm{SO}_{2}, \mathrm{NOx}$ ) (Data influenced by fresh emissions from vehicles were removed).

$\mathrm{NO}_{3}{ }^{-}$) in particles and precursor gases ( $\mathrm{SO}_{2}$ and $\mathrm{NOx}$ ) were investigated (see Fig. 13). The results indicated that the secondarily formed ions in $\mathrm{PM}_{2}$ : were weakly associated with their precursors. and their concentration ratios (slopes) were also similar during both day and nighttime. Thus. the photochemical formation paths of nss- $\mathrm{SO}_{4}{ }^{--}$and $\mathrm{NO}_{3}{ }^{-}$in aerosols were unimportant.

Semi-volatile species. such as $\mathrm{NH}_{4} \mathrm{NO}_{3}$ and $\mathrm{NH}_{4} \mathrm{Cl}$. in $\mathrm{PM}_{z .5}$ can be present in the forms of gaseous precursors and/or the particle phase. depending on their thermodynamic properties. In general. they are primarily in the particle phase at 08:00-09:00 h in the moming. when the temperature is typically lowest and then in the gaseous precursors in the daytime as the temperature increases. However, in this study. the transition to gaseous precursors in the daytime may not have occurred because the maximum temperature was only about 8 ${ }^{\circ} \mathrm{C}$. As a result, the concentrations of $\mathrm{NO}_{3}^{-}$and $\mathrm{Cl}^{-}$did not show higher levels in the nighttime. On the contrary, the maximum levels of $\mathrm{NO}_{3}{ }^{-}$were observed frequently in the daytime as follows: 15:00 h (January 13) . 12:00-16:00 h (January 14). 15:00 h (January 15). 12:00 h (January 16), 11:00 h (January 17), 12:00 h (January 18), 12:00 h (January 19), 16:00 h (Jamuary 20). 13:00 h (January 21), and 12:00 h (January 23) (see Fig. 11).

The relationships between concentrations of species and meteorological parameters. such as rainfall and WS. were investigated. It rained from $20: 00 \mathrm{~h}$. January 12 to $16: 00 \mathrm{~h}$. January 13 and the maximum rainfall was $5 \mathrm{~mm}$ on 06:00.

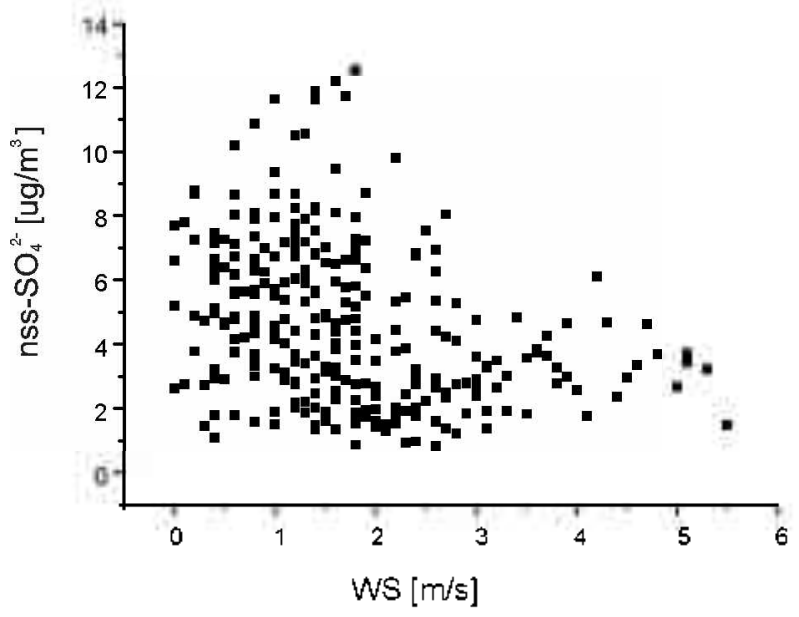

Figure 14. The scattergrams of wind speed (WS ) and $\mathrm{SO}_{4}{ }^{2-}$ in $\mathrm{PM}_{25}$.

January 13. Even though it rained on January 12-13, the washout effect was low because the intensity of rain was weak and no correlation was detected between rainfall and the levels of $\mathrm{PM}_{2}$ sionic species. It is to be noted that the WS was anti-correlated with levels in $\mathrm{PM}_{2}$ : (Fig. 11). Generally. WS increased in the daytime and decreased at night during the measurement period. It was about $\sim 1 \mathrm{~m} \mathrm{~s}^{-1}$ on January 12 and then steadily increased to $5 \mathrm{~m} \mathrm{~s}^{-1}$. Thereafter, it abruptly decreased at dawn on January 13. It maintained 1-2 $\mathrm{m} \mathrm{s}^{-\mathrm{J}}$ until January 18 , and increased again in the aftemoon of January 19. The WS approached $\sim 5 \mathrm{~m} \mathrm{~s}^{-1}$ as a maxinum in the daytime on January 22 and then decreased. These results showed a reverse trend to the levels of $\mathrm{PM}_{2.5}$, which were very low, especially on January 13 and January 20 when the WS was about $5 \mathrm{~m} \mathrm{~s}^{-1}$. Furthermore, the levels of $\mathrm{PM}_{2.5}$ were generally higher when the WS was relatively lower from January 14 to 18. Figure 14 shows scattergrams of WS and $\mathrm{SO}_{4}{ }^{2-}$ in $\mathrm{PM}_{25}$. $\mathrm{SO}_{4}^{2-}$ is thermodynamically stable. compared to the other ionic species. and thus its distributions are frequently controlled by the meteorological processes such as dispersion and advection of $\mathrm{PM}_{2}$. The results clearly indicated that $\mathrm{SO}_{4}{ }^{2-}$ levels were negatively correlated with WS. That is. as WS increased. the $\mathrm{SO}_{4}{ }^{2-}$ in $\mathrm{PM}_{2.5}$ decreased. These results showed that the concentrations of ionic species in $\mathrm{PM}_{2}$ s were closely associated with WS and the pollutants were dispersed actively as WS increased during the measurement period.

\section{Conclusions}

An instrument was developed to semicontinuously deternine $\mathrm{PM}_{2}$ ionic species. It has a shorter time resolution (20 min). compared to instruments using filter methods, and operated best at a sample flow rate of $16.7 \mathrm{~L} \mathrm{~min}^{-1}$. The particle collection section (mixing part. particle collection chamber. and air/liquid separator) was developed and optinized by sensitivity analyses of the PCEs using various types of test aerosols. The absolute uncertainties of size-resolved PCEs of the particle collection section in the range of $50-500 \mathrm{~nm}$ aerody namic particle diameter were found to be roughly of a magnitude of $\pm 10 \%$ at various water flow rates for steam 
generation and coil turns. The PCEs were almost $100 \%$ at different concentration levels in the range over $500 \mathrm{~nm}$ in diameter but $50-90 \%$ in the range of $50-500 \mathrm{~nm}$ under the following experimental conditions: 15 coil tums. a water flow rate for steam generation of $0.65 \mathrm{~mL} \mathrm{~min}^{-1}$, and an air sample flow rate of $16.7 \mathrm{~L} \mathrm{~min}^{-1}$. This technique was applied to field measurements of the chemical compositions of $\mathrm{PM}_{2.5}$ during January 11-24. 2006. at Yonsei University in Seoul. Korea. The results indicated that $\mathrm{SO}_{4}{ }^{{ }^{-}-}$and $\mathrm{NH}_{4}{ }^{-}$in $\mathrm{PM}_{2} 5$ were present at high levels from January 15 to 19 . Regression analyses between ions in $\mathrm{PM}_{2} \leq$ showed that $\left(\mathrm{NH}_{4}\right)_{2} \mathrm{SO}_{4} . \mathrm{Na}_{2} \mathrm{SO}_{4}, \mathrm{NH}_{4} \mathrm{Cl}$. and $\mathrm{NH}_{4} \mathrm{NO}_{3}$ were the major components. The concentrations of $\mathrm{PM}_{-5}$ ionic species during the measurement periods were influenced by a number of processes such as thermody namics. photochemical conversions. and meteorological transport. Of the processes. meteorological transport appeared to play the most important role in the variations of the ionic species.

Acknowledgments. This work was supported in part by the Brain Korea 21 Project. and by the Korea Science and Engineering Foundation (KOSEF) through the Advanced Environmental Monitoring Research Center (ADEMRC) at Gwangju Institute of Science and Technology (GIST). And this work was also supported in part by a research grant (PP09010) from the Korean Research Council of Public Science and Technology. The authors greatly acknowledge Prof. D. S. Lee and Prof. B. K. Lee (Yonsei University) for their supports during field measurement period. The authors wish to thank Korea Meteorological Administration (KMA) for supporting the meteorological data.

\section{References}

1. Charlson, R. J.; Schwartz, S. E; Hales, T. M.; Cess, R. D.; Coakley, J. A.; Hansen1, IT., J. E.; Hofmann, D. J. Science 1992, 255,423

2. Cass. G. R. Atmospheric Emiromment 1979, 13, 1069

3. Jacob, D. J. Amospheric Emiroment 2000, 3-, 2131

4. Docker, D. W. Pope, C. A. Anm. Rev Prblic Heath 1994, 15, 107.

5. Albrecht, B. A. Science 1989, 245, 1227.

6. Fowler, D.; Cape, J. N.: Sutton, M. A.; Mounte, R.; Hargreaves, K. J.; Duvzer, T. H.; Gallagher, M. W. In Acidification Research: Evaluation and Policu Applications; Proc. Int: Conf, 1992; 553.

7. On Res. Priorities for airbone particulate matter: National Research Conncil (NRC): Washington, D. C., 1998.

8. Slanina, J.; ten Brink, H. M.; Otjes, R. P.; Even, A.; Jongejan, P.; Khlystov, A.; Waijers-Ijpelaan, A.; Hu, M.: Lu, Y. Amospheric Enironment 2001, 35, 2319

9. Chow, J. C. Jounal of tir and Haste Management $1995,45,320$.
10. Buhr, S.: Buhr, M. P.; Fehsenfeld, F. C.: Holloway, I. S.: Karst, U.; Norton, R. B.; Panish, D. D.: Sievers, R. E. Atmosphenic Enviroment 1995, $29(1) 2609$

11. Khlystov, A.: Wyers, G. P.; Slanina, I Atmosphenic Emmoment 1995, 29, 2229

12. Simon, P. K.: Dasgupta, P. K. Analytical Chemistry 1995, 67, 71

13. Lill, S.: Dasgupta. P. K. Anahrical Chemistn 1996, 68, 3638.

14. Weber, R. Orsini, D: Daur, Y: Lee, Y. N.; Klotz, P. T.; Brechtel. F. Aerosol Science and Technologr 2001, 35, 718 .

15. Boring, C. B.; Al-Horr, R.; Genfa, Z.; Dasgupta, P. K.; Martin, M. W.; Smith, W. F. Analutical Chemistry 2002, 7t, 1256

16. Al-Hon, R.: Samanta, G.: Dasgupta, P. K. Environmental Science and Technologv 2003, 37, 5711

17. Hinds, W. C. Aerosol Technology: Properties, Behariors, and Measurement of Airbonne Panticles; John Wiley \& Sons: 1982; p 214

18. Seinfeld. I.: Pandis. S. Atmospheric Chemistny and Phssics: From Air Pollation to Climate Change; Wiley-interscience: New York. 1998: p 355.

19. Orsini, D. A.; Ma, Y.; Sullivan, A.; Sierau, B.; Baumant, K.; Weber, R. I. Amospheric Emiroment 2003, 37,1243

20. Maxwell-Meier, A.; Weber, R.; Song, C.: Orisi, D.; Ma, Y.; Camichael, G. R. Streets, D. G. Jommal of Geophysical Researth 2004, 109, D19807.

21. URG operation manual, Lse and Haintenance of LRG Annular. Denuders 2000, 25.

22. Park. S. S.: Hong. S. B.: Jung. Y. G.: Lee. I. H. Atmospheric Enirontent 2004, 38, 293.

23. Lee. I. H.: Y. Chen. I.: Tang. N. Envirommental Science and Techology $1991,25,339$

24. Kim, Y. P.; Seinfeld, J. H.; Saxena, P. Aerosol Science and Techologv 1993a, 19, 157.

25. Kim, Y. P.: Seinfeld J. H.: Saxena, P. Aerosol Science and Techolog, 1993b, 19, 182

26. Kim, D. S.: Lee, D. S.: Woo, C. G.: Choi, M. Jommal of Aerosol Science 2006, 37, 1876 .

27. Kim, D. S.: Kang, C. H.; Hong, S. B.: Lee, K. W.: Lee, J. H. Joumal of Korean Society for Amospheric Emiroment 2008, $2 *(\mathrm{E} 1), 24$.

28. Skoog, D. A.; West, D. M.; James Holler, F.: Crouch, S. R. Anahtical Chentisty: An introduction; Brooks/Cole: 2000; p 140.

29. Hinds, W. C. Aerosol Techology: Properties, Behoriors, and Heastmement of Airbonne Panticles, John Wiley \& Sons: 1982; p 24.

30. Chun, Y. S.: Kim, I. Y.: Choi, J. C.: Boo, K. O.: Oh, S. N.; Lee, M. H. Atmospheric Emiromment 2001, 35, 2715.

31. Báe. G. N.: Kim. M. C.: Lim. D. Y: Moon. K. I.: Baik, N. I. Joumal of Korean Society for Amospheric Enviroment 2003, 19(2). 167.

32. Song, C. H.; Canmichael, G. R. Atmospheric Enviromment 1999. 33,2203

33. Song, C. H.; Carmichal, G. R. Jommal of Geophnsical Reseanch 2001, 106,18131

34. Hong, S. B.; Kim, D. S.; Ryu, S. Y.: Kim, Y. I.: Lee, I. H. Atmospheric Research 2008, 89,62. 